\title{
Comparison of students' motivation at different phases of medical school
}

\author{
Gabriel Mendes Corrêa da Silva' \\ Amanda Ribeiro Borges ${ }^{1}$ \\ Oscarina da Silva Ezequie/1 \\ Alessandra Lamas Granero Lucchetti ${ }^{1}$ \\ (D) Giancarlo Lucchetti ${ }^{1}$
}

1. School of medicine, Federal University of Juiz de Fora, Juiz de Fora (MG),Brasil

http://dx.doi.org/10.1590/1806-9282.64.10.902

\section{SUMMARY}

INTRODUCTION: Knowledge about student motivation allows educators to broaden their understanding and to establish strategies that make it possible to enhance motivation.

OBJECTIVES. To investigate the levels of student motivation at different phases of medical education, comparing incoming students' motivation with that of those at the end of their studies, as well as during the different preclinical, clinical, and clerkship cycles.

METHOD: Cross-sectional study including students from a Brazilian public university. The questionnaire included sociodemographic data and the Academic Motivation Scale (AMS). Student motivation was compared at different phases of the medical course.

RESULTS: 710 students were included. Students in the preclinical phase (15t-2 $2^{\text {nd }}$ years) had higher levels of integrated regulation AMS (e.g., "Education is a privilege."), introjected regulation AMS (e.g."I come because it is what is expected of me."), and intrinsic motivation AMS (e.g. "School is a pleasure"). Students in the clinical phase ( $3^{\text {rd }}-4^{\text {th }}$ years) had higher levels of amotivation (e.g., "I'm wasting my time at school.") and external regulation AMS (e.g., "I'm coming to school to earn a degree"). AMS levels of external regulation, introjected relation, and integrated regulation were different for Clerkship students ( $5^{\text {th }}-6^{\text {th }}$ years) compared to preclinical students, but not for clinical students. Comparing only the first and last years, incoming students had higher levels of integrated regulation AMS and lower levels of amotivation AMS and external regulation AMS.

CONCLUSION: Important motivational changes were found during different phases of medical school, with higher levels of motivation during the course's initial semesters. These findings can aid in developing educational strategies to stimulate self-determined education.

KEYWORDS: Schools, Medical. Personal Autonomy. Students, Medical. Motivation. Behavior and Behavior Mechanisms.

\section{INTRODUCTION}

In recent years, the role of motivation in the teaching-learning process for medical students has been widely discussed. Motivation constitutes one of the indispensable affective components for effective learning in medical education, as well as for higher quality study patterns, better well-being, improved performance, and for training worthy professionals ${ }^{1,2}$.
Motivation is defined by the Oxford dictionary (https://en.oxforddictionaries.com/) as the "Desire or willingness to do something; enthusiasm“. Although there are several definitions of motivation, a more solid theory for this concept was lacking until the 80s when the Self-Determination Theory (SDT) was created $^{3}$. This is an important theory that defines

DATE OF SUBMISSION: 22-Jan-2018

DATE OF ACCEPTANCE: 22-may-2018

CORRESPONDING AUTHOR: Giancarlo Lucchetti

School of Medicine, Federal University of Juiz de Fora, Brasil

Avenida Eugênio do Nascimento s/n - Dom Bosco - Juiz de Fora, Brasil

E-mail: g.lucchetti@yahoo.com.br 
motivation as psychological energy directed at a particular goal $^{3}$, sustaining that motivation possesses different spectra, from amotivation (lack of motive to pursue an activity), passing through extrinsic motivation (the activity is an instrument to achieve a desirable result or to avoid the undesirable) and reaching intrinsic motivation (doing something for the pleasure inherent in the activity itself) ${ }^{4-6}$. The motivation's quality varies due to an innate process of internalization that can be stimulated or inhibited by external and internal factors. Satisfaction of three basic psychological needs is needed to stimulate and maintain intrinsic motivation: autonomy, competence, and belonging ${ }^{7}$.

Studies have attempted to evaluate the response to different patterns of motivation. In relation to medical students, a Dutch study found a positive correlation between high intrinsic motivation and more study time, deeper study strategies, and less exhaustion ${ }^{8}$. Corroborating those findings, a Brazilian study found that motivation is associated with valuing the course, level of academic achievement, and greater student self-confidence ${ }^{9}$.

However, beyond evaluating which factors are associated with motivation, we need to understand motivational changes during the course's different phases, thus permitting the planning of new educational strategies and curriculum changes. In fact, studies have been undertaken in an attempt to understand university students' motivational patterns. In a study of 856 undergraduate students in 30 courses at an American college, a decline in both intrinsic motivation and extrinsic motivation was found ${ }^{10}$. These results are similar to those of other studies conducted in areas both related and unrelated to healthcare ${ }^{11,12}$. Specifically, in relation to medical students, a Brazilian study ${ }^{13}$ evaluated 85 first year students and found an increase in the indices of anxiety and a decrease in academic motivation after 12 months, demonstrating that, in a short period of time, it is already possible to demonstrate motivational changes in students. According to the authors, the possible cause for these findings may be related to the curriculum of the first year, in which the disciplines deal primarily with concepts that are not directly related to the practice of the profession chosen by the freshmen student.

Knowledge about student motivation allows educators to broaden their understanding and to establish strategies that can increase their potential, as well as reduce factors that foster amotivation. Despite this relevance, few studies have evaluated student motivation during the different phases of medical studies. SDT has also been little used in this context. Considering this need, our study attempts to investigate the levels of student motivation at different phases of their medical education, comparing incoming students' motivation with that of those at the end of their studies, as well as during the different preclinical, clinical, and clerkship cycles. With that strategy, our objective has been to see which types of motivation do or do not undergo changes and what the probable hypotheses for those changes would be.

\section{METHODS}

Participants and Design of the Study

A Cross-sectional study including students during the six years (12 semesters) of the medical school at the Federal University of Juiz de Fora (UFJF, acronym in Portuguese) was carried out in 2016. All students enrolled in one of the three phases of medical school (preclinical $-1^{\text {st }}$ and $2^{\text {nd }}$ years, clinical $-3^{\text {rd }}$ and $4^{\text {th }}$ years, and clerkship $-5^{\text {th }}$ and $6^{\text {th }}$ years) were invited to participate. Students who were not in Brazil due to exchange activities, who were doing their clerkship in another city, who were not present when data was collected, or who did not wish to participate were excluded.

The project was approved by the UFJF University Hospital's Ethics in Research Committee, registered under the number 13767322015. All participants signed an informed consent.

\section{Procedures}

Data collection was done in medical course classrooms, before or after educational activities. The questions were applied as follows: students were given both questionnaires after a brief explanation of study's objectives and the complete fill of the consent form. Students were guaranteed that their information would be confidential.

\section{INSTRUMENTS}

The self-applied questionnaire took about 20 minutes to answer and included the following data:

Sociodemographic data: age, ethnicity, civil status, and course year in which enrolled.

Academic Motivation Scale (AMS): we used the 
scale developed by Vallerand et al. ${ }^{14,15}$, which was translated, validated, and adapted for Portuguese after undergoing factorial analysis ${ }^{9,16}$. This questionnaire, used to evaluate student motivation for learning, is made up of 31 items. The global scale had a Cronbach alpha of 0.817 in the present study. Likert scale answers range from one to seven, with one being "does not correspond at all" and seven being "corresponds exactly". The scale is subdivided into seven subscales:

- Amotivation (Cronbach alpha: 0.864 for this study) - composed by six items (e.g. "Honestly, I don't know why I come to school”, “I don't see why I should come to school"),

- Extrinsic motivation through external regulation (Cronbach alpha: 0.684 for this study) composed by five items (e.g., "I come to school to not get marked absent", "I come to school to earn a degree"),

- Extrinsic motivation through introjected regulation (Cronbach alpha: 0.795 for this study) composed by six items (e.g., "I come because it is what's expected of me", "to show myself that I am an intelligent person”);

- Extrinsic motivation through identified regulation (Cronbach alpha: 0.560) for this study) - composed by two items (e.g. "I come because frequenting classes is necessary for learning”, "because I think that requiring attendance is needed so students will take the course seriously")

- Extrinsic motivation through integrated regulation (Cronbach alpha: 0.794 for this study) composed by four items (e.g. "because education is a privilege", "because studying broadens our horizons"),

- Intrinsic motivation (Cronbach alpha: 0.744 for this study) - composed by three items (e.g., "because the university is a pleasure for me", "because I really like going to school")

- Extrinsic motivation through social regulations (Cronbach alpha: 0.567 for this study) - composed by four items (e.g. "I come to school to get out of the house", "to see my friends is the main reason I come to the university".)

\section{Data Analysis}

Descriptive analysis was carried out using frequency and percentage or mean and standard deviation. Inferential analysis was then performed.
Students were divided into three groups according to their undergraduate phase (preclinical $-1^{\text {st }}$ and $2^{\text {nd }}$ years, clinical $-3^{\text {rd }}$ and $4^{\text {th }}$ years, and clerkship $-5^{\text {th }}$ and $6^{\text {th }}$ years). To compare student motivation among different phases of the undergraduate medical course, we compared the scores of each of the Academic Motivation Scale's subdimensions using independent t-test or one-way ANOVA for independent samples with a Tukey post hoc test. Two analyses were performed, the first comparing preclinical, clinical, and clerkship students and the second comparing students in the first semester with students in the last semester of the medical course. All analysis was performed using SPSS version 21 (SPSS Inc.). A $\mathrm{p}<0.05$ was considered significant.

\section{RESULTS}

A total of 710 students were included (response rate $70.5 \%$ ), from which 265 (37.3\%) were enrolled in the preclinical years, $233(32.8 \%)$ in the clinical years, and $212(29.9 \%)$ in the clerkship. Most students were female (55.4\%), single (98.0\%), and white (66.9\%) with a mean age of 22.11 (SD: 3.11) years.

Figure 1 shows the comparison among the different subdimensions of the Academic Motivation Scale among the course's distinctive phases. Comparing to the preclinical phase, the clinical phase had higher scores in the amotivation AMS $(\mathrm{p}=0.007)$ and external regulation AMS ( $p<0.001)$ and lower scores in the integrated regulation AMS ( $\mathrm{p}=0.007)$, and intrinsic motivation AMS ( $p=0.044)$. Likewise, the clerkship phase had higher scores in the external regulation AMS ( $p=0.024)$ and lower scores in the introjected regulation AMS ( $\mathrm{p}=0.006)$, and integrated regulation AMS ( $<<0.001)$. Differences between the clinical period and clerkship were not verified.

Figure 2 compares the academic motivation scale's different subdimensions between the course's first and last semesters. The last semester had lower scores in the amotivation AMS $(\mathrm{p}<0.001)$ and in the external regulation motivation AMS $(\mathrm{p}=0.006)$, and and higher scores in the integrated regulation AMS $(p<0.001)$.

\section{DISCUSSION}

This study has shown that there are significant differences in motivation in medical course phases. Students in the preclinical phase have higher levels 
FIGURE 1: LEVELS OF MOTIVATION IN THE PRECLINICAL, CLINICAL, AND CLERKSHIP PHASES OF MEDICAL SCHOOL\#

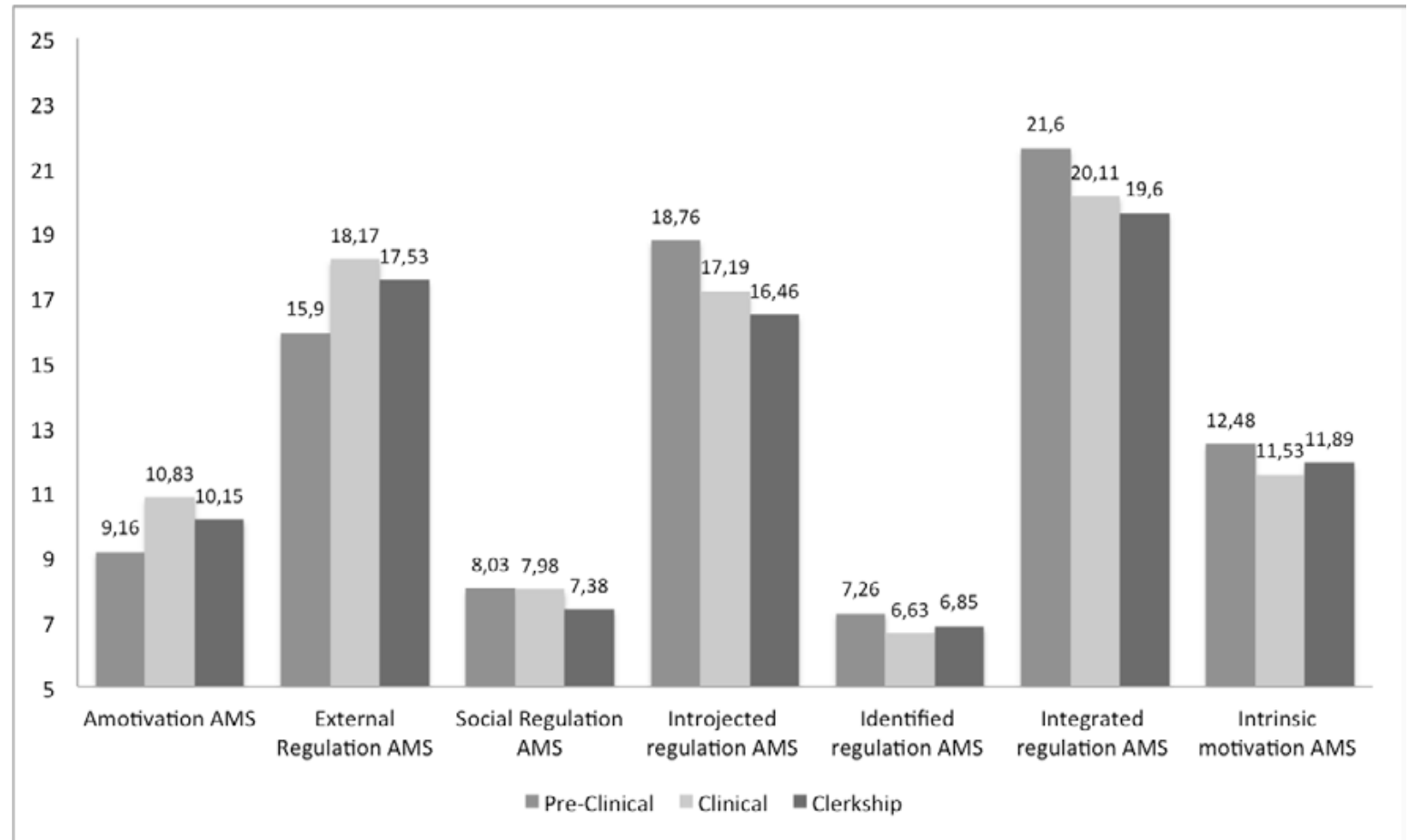

* $p<0.05$ \#Amotivation AMS (e.g. "I am wasting my time in school"), External regulation AMS (e.g. "I come to school to complete my degree"), Social regulation AMS (e.g. "I come to school to get out of the house"), Introjected regulation AMS (e.g. "I come because it is what is expected of me"), Identified regulation AMS (e.g. "I come because I must attend classes to learn"), Integrated regulation AMS (e.g. "Education is a privilege"), Intrinsic motivation AMS (e.g. "school is a pleasure")

FIGURE 2: LEVELS OF MOTIVATION COMPARING THE FIRST AND LAST SEMESTERS OF MEDICAL SCHOOL\#

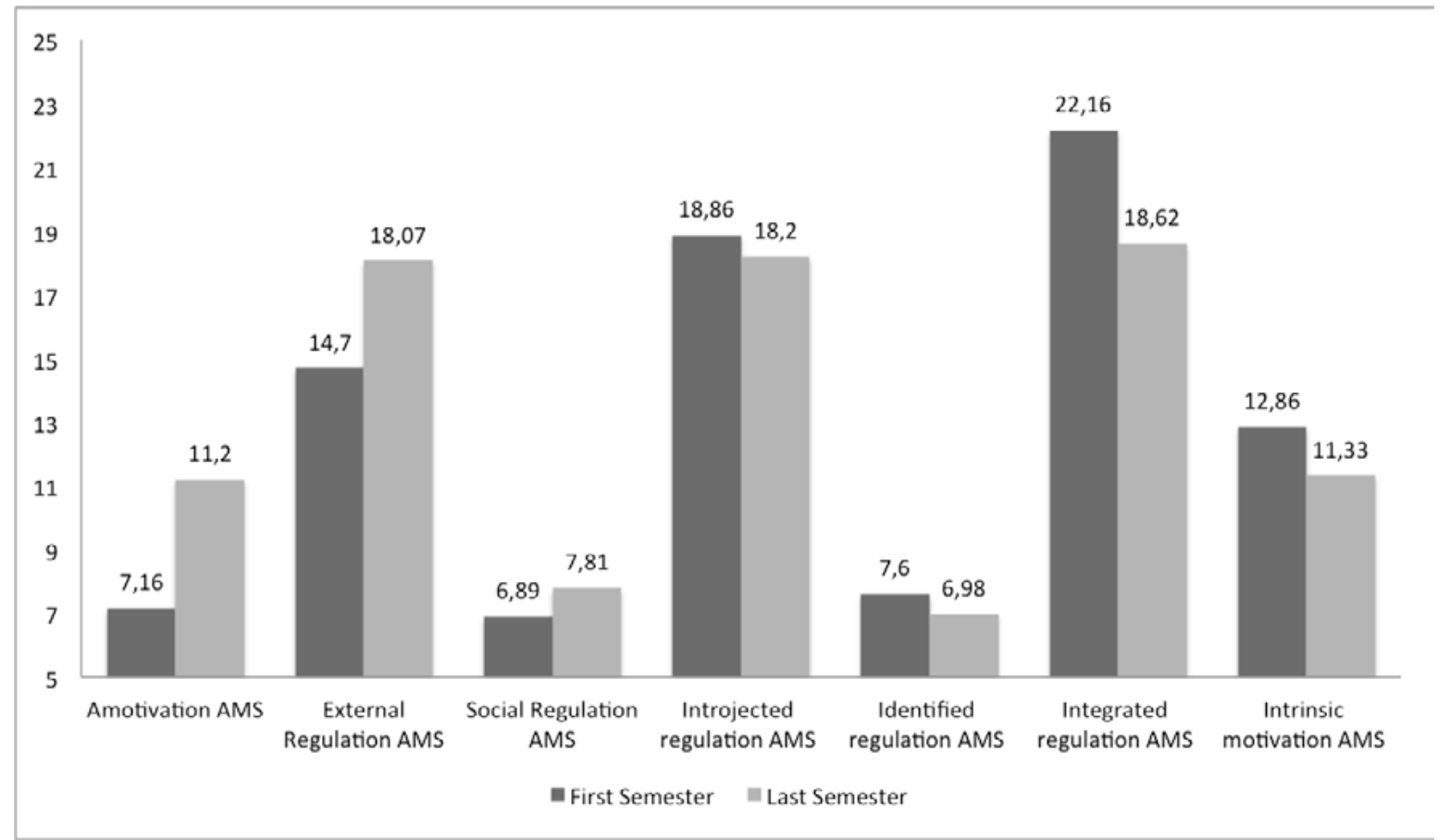

"p<0.05 "Amotivation AMS (e.g. "I am wasting my time in school"), External regulation AMS (e.g. "I come to school to complete my degree"), Social regulation AMS (e.g. "I come to school to get out of the house") Introjected regulation AMS (e " "I come because it is what is expected of me"), Identified regulation AMS (e. "I come because I must attend classes to learn"), Integrated regulation AMS (e.g. "Education is a privilege"), Intrinsic motivation AMS (e.g. "school is a pleasure") 
of integrated regulation AMS (e.g. "Education is a privilege"), introjected motivation AMS (e.g. "I come because it is what's expected of me") and intrinsic motivation AMS (e.g. "school is a pleasure"). On the other hand, students in the clinical phase have higher levels of amotivation AMS (e.g. "I'm wasting my time at school") and external regulation AMS (e.g., "I come to school to earn a degree"). Clerkship students had results that were non-significant in relation to the clinical period, but different in relation to the preclinical in external regulation AMS, introjected regulation AMS, and integrated regulation AMS. Comparing only the first and last semester of the course, incoming students had higher levels of integrated regulation AMS, and lower levels of amotivation AMS and external regulation AMS. We will discuss some explanations for these findings below.

In relation to high motivation in first period (semester) students, this result concurs with other studies ${ }^{4,9}$ and is related to factors that might be difficult for the educational institution to modify. Greater intrinsic motivation at the outset of the course comes from the very choice to pursue a career in medicine as a doctor, which is influenced by factors inherent on student's sociocultural profile (e.g. age, ethnicity, support from parents and professors, higher socioeconomic level), personality traits (self-transcendence and self-directedness), higher socioeconomic level, greater altruism, and the novelty experienced at the beginning of the course, as well as the search for challenges $4,9,17,18$.

Once a student enters medical school, motivation begins to depend not only on the student's inherent characteristics, but also on questions related to the learning environment, curriculum, and strategies provided by the medical school. In this context, our study has shown that there are marked differences among the course's phases. Comparing with the scientific literature in the area, Brouse et al..$^{10}$ and Hakan \& Münire" ${ }^{11}$ have shown a decrease in the self-determined motivation over the course of undergraduate studies, which can be also observed in our study during the clinical period, with higher values of amotivation (e.g. "I'm wasting my time at school") and of extrinsic motivation through external regulation (e.g. "I come to school to earn a degree") and lower levels of extrinsic motivation through integrated regulation (e.g. "Education is a privilege"). This corroborates the idea that higher education courses in general fail to stimulate and maintain the more intrinsic forms of motivation. The drop in intrinsic motivation from the preclinical to clinical phases is in line with Del-Ben et al. ${ }^{13}$ 's findings which suggested that one of the mechanisms is the lack of greater clinical contextualization between theoretical disciplines and medical practice. In our context, the clinical phase still has classes that are mostly theoretical, a high course load, and little contact with patients, which can explain students' low motivation.

In the preclinical and clerkship relationship, we note the lack of difference in the fields of amotivation (e.g. "I'm wasting my time at school"), intrinsic motivation (e.g., "school is a pleasure"), extrinsic motivation through social regulations (e.g. "I come to school to get out of the house"), and extrinsic motivation through identified regulation (e.g., "I come to school because I must attend classes to learn"). The lack of difference between preclinical and clerkship phases and, in contrast, the drop in these variables during the clinical phase, can be explained by the increase in clerkship students' responsibilities, related to higher intrinsic motivation, as pointed out by another study ${ }^{19}$ involving primary care clerkship students in the United Kingdom. Its results demonstrated that greater responsibility for patients and clinical practice positively contribute to reinforcing and sustaining the student's self-determined profile. Another possibility is insertion itself in the field of practice, which in and of itself can stimulate self-determined motivation.

Nevertheless, the fact that students in the course's final semester have higher amotivation (e.g. "I'm wasting my time at school") and extrinsic motivation through external regulation (e.g. "I come to school to earn a degree") than beginning students is an important finding. These results are of concern if we consider that this last educational phase involves intense clinical contact and proximity to the moment of "becoming a doctor". These findings differ from those of other studies mentioned in literature which show that last year students tend to be more altruistic and think about alleviating patient suffering in detriment to the secondary benefits of a medical career $^{20,21}$. We can speculate that, in the Brazilian context, great competitiveness and the lack of openings for medical residences can result in higher levels of stress ${ }^{18}$ and, consequently, amotivation for clinical activities in detriment to greater hours of study time due to the extremely cognitive tests in the selection process for spaces in residency programs.

This notable change in medical students during 
different phases and motivational decline with the passage of time can be explained by a curricular structure based more on the cognitive component of learning ${ }^{22}$, in that it minimizes the importance of motivational factors and enhances competitiveness, hence contributing to the increase in amotivation and forms of extrinsic motivation ${ }^{23}$. Thus, the need, especially during the clinical period, for an andragogic proposal to approach motivation through techniques like offering an environment of choices and freedom in order to facilitate empowerment so that students can assume greater responsibility for their learning process; to furnish a well-structured orientation so students are successful, without failing to value their work, allowing them to feel comfortable and free to express their opinions and foment their interest in subjects and tasks ${ }^{5,24}$.

Another potential explanation is the learning environment that students are exposed. Positive (i.e. active learning, professional environment, ethical teachers) and negative aspects of this environment (i.e. hazing, unethical behaviors, hidden curriculum) may be responsible to worse outcomes in medical education, including mental health problems, loss of empathy and burnou ${ }^{25,26}$. However, few studies have already found that a worse learning environment can be correlated to worse levels of motivation ${ }^{27,28}$. Further studies should be carried out in order to elucidate the possible causes of this relationship.

This study has some limitations that we should consider. Being a cross-sectional study, variations between the university periods can be a bias for each specific group's motivation profile. The same question can be identified in the vast majority of studies of motivation in medical education ${ }^{4}$. Studies that focus on longitudinal follow up could throw light on fluctuations in the motivational profile over the course of medical studies. Further, factors that influence motivation as a mutable variable, presented by Kusurkar et al. ${ }^{4}$ - such as the type of curriculum, form of evaluations, precocious insertion in the field of practice, greater perception of autonomy (as in primary care scenarios), and the sensation of greater well-being - were not investigated in this study, with their presence or absence in the preclinical, clinical, and clerkship periods being related to the variations encountered.

On the other hand, this study contributes to knowledge of the variability of medical students' motivational profile during undergraduate studies. As the SDT is little known in the field of medical education, in spite of advances in understanding motivation for learning ${ }^{7}$, this study increases its visibility for understanding and application in medical teaching. Furthermore, this study permits actions designed to develop self-determined motivation in these students be planned and executed in accordance with the peculiarities of each period.

\section{CONCLUSION}

In conclusion, our findings reinforce the fact that there are important motivational changes among the different phases of medical school, with there being greater levels of motivation during the course's initial period. These findings can aid in developing educational strategies to stimulate self-determined motivation, fomenting the intrinsic part of motivation so that the disposition to practice and to learn will be stimulated in students in a more genuine way, with the view of prolonging their desire to learn after graduating through contributions by educators during their academic life, bringing improvements to students' medical careers.

\section{RESUMO}

INTRODUÇão: O conhecimento sobre a motivação dos estudantes possibilita aos educadores ampliar sua compreensão e estabelecer estratégias que possam potencializá-la.

OBJETIVOS: Investigar a motivação do estudante em diferentes momentos da formação médica, comparando-se a motivação de alunos ingressantes e do final do curso, assim como nas diferentes fases pré-clínica, clínica e internato.

MÉTODOS: Estudo transversal incluindo estudantes de uma universidade pública brasileira. O questionário incluiu dados sociodemográficos e a Escala de Motivação Acadêmica (EMA). A motivação dos estudantes foi comparada nas diferentes fases do curso.

RESULTADOS: Foram incluídos 710 estudantes de medicina. Houve diferenças significantes entre a motivação nas diferentes fases do curso de medicina. Estudantes nas fase pré-clínica ( $1^{\circ}$ e $2^{\circ}$ anos) possuíam maiores níveis de EMA regulação integrada (e.g. "Educação é um privilégio"), EMA regulação introjetada (e.g. "venho porque é isso que esperam de mim") e EMA motivação intrínseca (e.g. "universidade é um prazer"). Já estudantes da fase clínica (30 e $4^{\circ}$ anos) possuíam maiores níveis de EMA desmotivação (e.g. "estou perdendo meu tempo na universidade") e EMA regulação externa (e.g. "venho à universidade para conseguir o diploma"). Os estudantes do internato ( $5^{\circ}$ e $6^{\circ}$ anos) obtiveram resultados não significantes em relação ao período clínico, mas diferentes em relação ao 
pré-clínico na EMA regulação externa, EMA regulação introjetada e EMA regulação integrada. Comparando-se apenas o primeiro com o último semestre do curso, os alunos ingressantes possuíam maiores níveis de EMA regulação integrada e menores níveis de EMA desmotivação e EMA regulação externa.

CONCLUSÃO: Foram encontradas mudanças motivacionais importantes entre as diferentes fases da formação médica, tendo maiores níveis de motivação nos períodos iniciais do curso. Esses achados podem auxiliar o desenvolvimento de estratégias educacionais que estimulem a educação autodeterminada.

PALAVRAS-CHAVE: Faculdades de medicina. Autonomia pessoal. Estudantes de medicina. Motivação. Comportamento e mecanismos comportamentais.

\section{REFERENCES}

1. Sockalingam S, Wiljer D, Yufe S, Knox MK, Fefergrad M, Silver I, et al. The relationship between academic motivation and lifelong learning during residency: a study of psychiatry residents. Acad Med. 2016;91(10):1423-30.

2. Park J, Chung S, An H, Park S, Lee C, Kim SY, et al. A structural model of stress, motivation, and academic performance in medical students. Psychiatry Investig. 2012;9(2):143-9.

3. Patrick $H$, Williams GC. Self-determination theory: its application to health behavior and complementarity with motivational interviewing. Int J Behav Nutr Phys Act. 2012;9:18.

4. Kusurkar RA, Ten Cate T], van Asperen M, Croiset G. Motivation as an independent and a dependent variable in medical education: a review of the literature. Med Teach. 2011;33(5):e242-62.

5. Orsini $C$, Evans $P$, Jerez $O$. How to encourage intrinsic motivation in the clinical teaching environment?: a systematic review from the self-determination theory. J Educ Eval Health Prof. 2015;12:8.

6. Ryan RM, Deci EL. Self-determination theory and the facilitation of intrinsic motivation, social development, and well-being. Am Psychol. 2000;55(1):68-78

7. Ten Cate TJ, Kusurkar RA, Williams GC. How self-determination theory can assist our understanding of the teaching and learning processes in medical education. AMEE guide No. 59. Med Teach. 2011;33(12):961-73.

8. Kusurkar RA, Croiset G, Galindo-Garré F, Ten Cate O. Motivational profiles of medical students: association with study effort, academic performance and exhaustion. BMC Med Educ. 2013;13:87.

9. Sobral DT. Learner's motivation in medical studies: use of the academic motivation scale. Psic: Teor e Pesq. 2003;19(1):25-31.

10. Brouse CH, Basch CE, LeBlanc M, McKnight KR, Lei T. College students' academic motivation: differences by gender, class, and source of payment. College Quarterly. 2010;13(1). [cited 2017 Dec 5] Available from: https:// files.eric.ed.gov/fulltext/EJ912093.pdf

11. Hakan K, Münire E. Academic motivation: gender, domain and grade differences. Procedia-Social and Behavioral Sciences. 2014;143:708-15.

12. Leal EA, Miranda G), Carmo CRS. Teoria da autodeterminação: uma análise da motivação dos estudantes do curso de ciências contábeis. Rev Contab Finanç. 2013;24(62):162-73.

13. Del-Ben CM, Machado VF, Madisson MM, Resende TL, Valério FP, Troncon LE. Relationship between academic performance and affective changes during the first year at medical school. Med Teach. 2013;35(5):404-10.

14. Vallerand RJ, Blais MR, Brière NM, Pelletier LG. Construction et validation de l'échelle de motivation en éducation (EME). Canad I Behav Sci/Rev Canad Sci Comp. 1989;21(3):323-49.
15. Vallerand R/, Pelletier LG, Blais MR, Brière NM, Senecal C, Vallieres EF. On the assessment of intrinsic, extrinsic, and amotivation in education: evidence on the concurrent and construct validity of the Academic Motivation Scale. Educ Psychol Meas. 1993;53(1):159-72.

16. Guimarães SÉR. Psychometric properties of an instrument for assessing the motivation of university students. Ciências \& Cognição. 2008;13(1):101-13.

17. Sobral DT. Self-determined motivation in medical students: correlations with preference reasons and the intention to pursue the medical course. Rev Bras Educ Med. 2008;32(1):56-65.

18. Moutinho IL, Maddalena NC, Roland RK, Lucchetti AL, Tibiriçá SH, Ezequiel OD, et al. Depression, stress and anxiety in medical students: a cross-sectional comparison between students from different semesters. Rev Assoc Med Bras. 2017;63(1):21-8.

19. Cantillon $P$, Macdermott M. Does responsibility drive learning? Lessons from intern rotations in general practice. Med Teach. 2008;30(3):254-9.

20. Powell A, Boakes |, Slater P. What motivates medical students: how they see themselves and their profession. Med Educ. 1987;21(3):176-82.

21. Burstein AG, Loucks S, Kobos J, Johnson G, Talbert RL, Stanton B. A longitudinal study of personality characteristics of medical students. J Med Educ. 1980;55(9):786-7.

22. Lucchetti G, Damiano RF, DiLalla LF, Lucchetti ALG, Moutinho ILD, Silva Ezequiel $O$, et al. Cross-cultural differences in mental health, quality of life, empathy, and burnout between US and Brazilian medical students. Acad Psychiatry. 2018;42(1):62-7.

23. Kusurkar RA, Croiset G, Custers E, Ten Cate O. Development of motivation theories and how they relate to development of medical education. Motivation Med Students. 2012:37.

24. Baeten M, Dochy F, Struyven $K$. The effects of different learning environments on students' motivation for learning and their achievement. $\mathrm{Br}$ Educ Psychol. 2013;83(Pt 3):484-501.

25. Dyrbye LN, Thomas MR, Harper W, Massie FS Ir, Power DV, Eacker A, et al. The learning environment and medical student burnout: a multicentre study. Med Educ. 2009;43(3):274-82.

26. Tackett $S$, Wright $S$, Lubin $R$, Li J, Pan $H$. International study of medical school learning environments and their relationship with student well-being and empathy. Med Educ. 2017;51(3):280-9.

27. Aktas $Y Y$, Karabulut N. A survey on Turkish nursing students' perception of clinical learning environment and its association with academic motivation and clinical decision making. Nurse Educ Today. 2016;36:124-8.

28. Opdenakker MC, Minnaert A. Relationship between learning environment characteristics and academic engagement. Psychol Rep. 2011;109(1):259-84. 